\title{
Reti e nodi nella città di Berat in Albania
}

\author{
Adriana Trematerra
}

\section{Abstract}

II contributo propone lo studio delle architetture religiose della città di Berat in Albania, sito Patrimonio dell'Umanità a partire dal 2008 e raro esempio di convivenza di molteplici fedi, e si inserisce in un percorso di conoscenza più ampio incentrato sullo studio dei complessi religiosi situati nell'ambito geografico dei Balcani. Nello specifico, verranno analizzate la chiesa ortodossa dei Santi Costantino ed Elena, la moschea Rossa, la moschea Bianca e la moschea degli Scapoli destinate, queste ultime, al culto islamico. Lo scopo della presente indagine vuole essere quello di descrivere e di illustrare i manufatti architettonici analizzati attraverso il disegno di architettura, con l'obiettivo di strutturare un percorso di conoscenza in grado di innescare riflessioni circa la conservazione critica e la valorizzazione del culto religioso al fine di proteggere quel patrimonio urbano e paesaggistico tramandato nei secoli da diverse culture che hanno definito le attuali configurazioni dei manufatti analizzati.

Parole chiave

disegno, rilievo, conoscenza, religione, architettura.

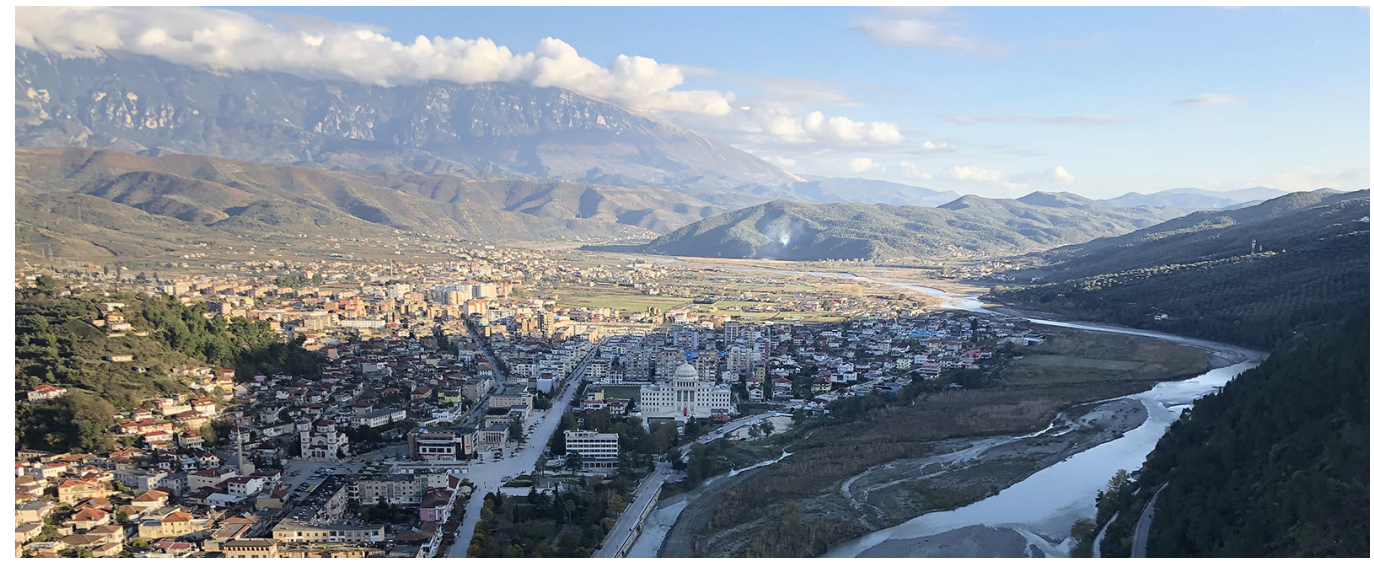




\section{Introduzione}

La ricerca prende forma, in primo luogo, attraverso l'analisi del termine 'connettere', ovvero "congiungere, annodare [...] creare un collegamento fra elementi", "mettere in relazione due o più fatti, concetti" ' I] con l'obiettivo di individuare un suo sinonimo con il quale dar vita alla presente ricerca. Tra questi ultimi è stato individuato il termine 'rapportare', ovvero "mettere in rapporto, confrontare una situazione, una grandezza, una quantità con un'altra" [2]. La città di Berat è, da sempre, considerata il paesaggio della secolare convivenza di diverse fedi: cristiani cattolici e ortodossi, musulmani e bektaschi che, nei secoli, hanno testimoniato uno straordinario esempio di coabitazione religiosa e di rispetto reciproco [3]. Un luogo in cui vi è un profondo 'rapporto', e quindi una profonda 'connessione', tra diverse culture religiose che hanno determinato la realizzazione di diverse strutture architettoniche che da secoli convivono armoniosamente sullo stesso territorio. La città di Berat, inserita nel 2008 nella lista dei siti Patrimonio dell'Umanità, conserva ancora oggi complessivamente 42 edifici religiosi, cristiani e musulmani ed è suddivisa in 3 quartieri: Kala, allinterno delle mura della vecchia fortezza, in cima alla collina sulla riva sinistra del fiume Osum, Mangalem, lungo la collina e verso il fiume, Gorica, il quartiere cristiano, in piano, oltre il fiume Osum incastonato tra i monti. Kala, il più vario dei quartieri, con circa trenta chiese e i resti di due moschee, conserva quasi intatto il suo carattere, con strade definite dai muri di cinta dei giardini e da quelli delle case con parti aggettanti, di legno e ampiamente vetrate, e con tetti ricoperte da tegole rosse a leggero spiovente. II quartiere, a $187 \mathrm{~m}$ sopra il livello del mare con una superficie di 9,6 ettari, è costituito dal castello contornato da imponenti mura di tipologia ellenistica e successiva rimodulazione medievale con 24 torri di forma e dimensione diversa. Del castello si conservano, inoltre, i sotterranei coperti da volte a botte di mattoni sorrette da poderose colonne alte 10 metri. Delle numerose strutture religiose presenti ne sono state analizzate tre: la chiesa dei Santi Costantino ed Elena, i resti della moschea Bianca e quelli della moschea Rossa.

Particolarmente compatto è, invece, il quartiere musulmano di Mangalem, inizialmente adibito a bazar con residenze di mercanti e artigiani, oggi costituito maggiormente da abitazioni, il quale si estende sul ripido pendio formando una figura triangolare sulla cui cima si trova il

Fig. I. La città di Berat, planimetria generale con individuazione della Chiesa dei Santi Costantino ed Elena, della Moschea Bianca, della Moschea Rossa e della Moschea degli Scapoli.

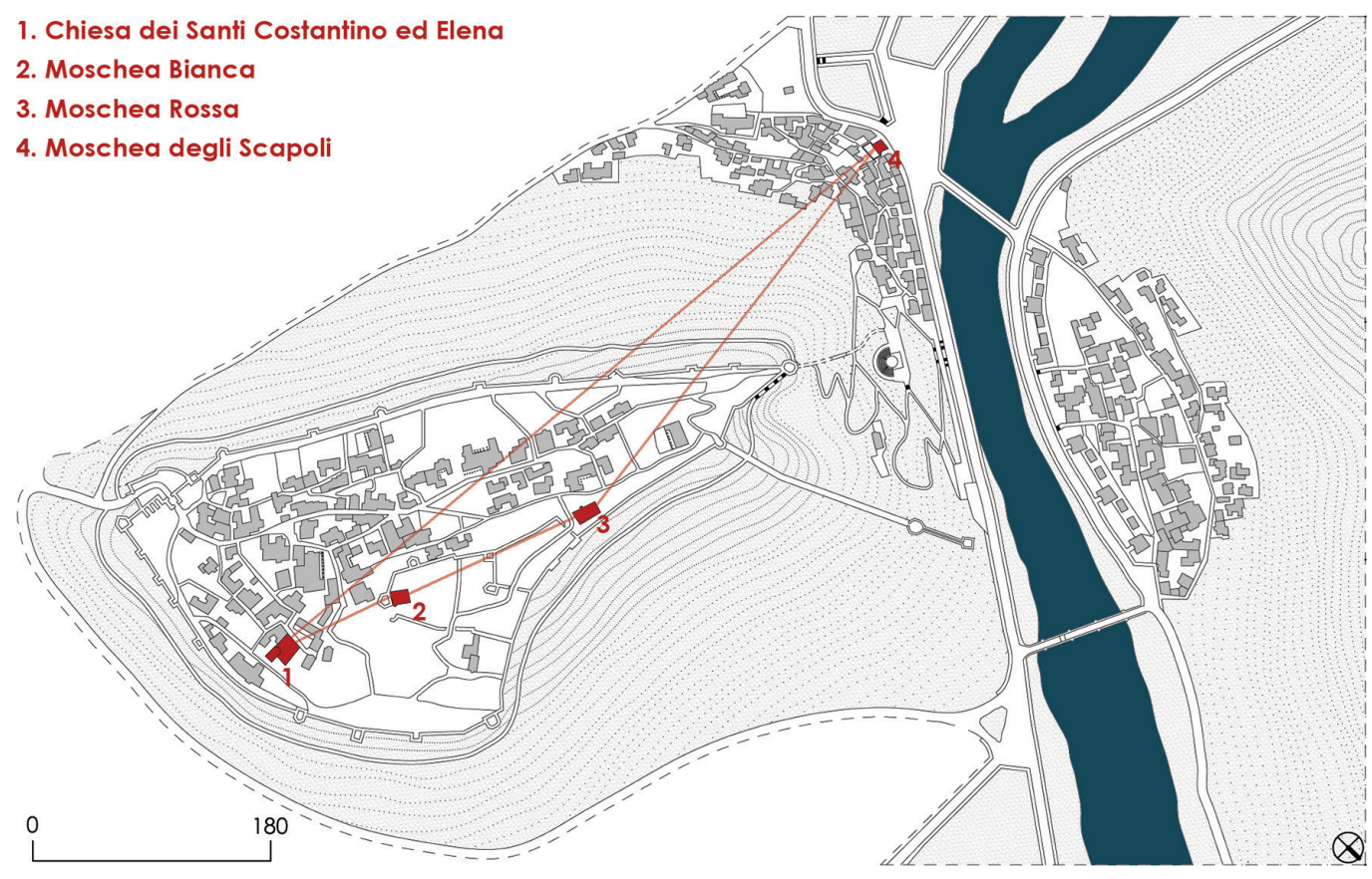


castello. La principale caratteristica del borgo sono le 100 I finestre delle abitazioni e delle strutture pubbliche.Vi sono alcune moschee tra le quali è stata analizzata la moschea degli Scapoli.

Infine, il quartiere cristiano ortodosso di Gorica, sviluppatosi nel XVI secolo sulla sponda destra del fiume Osum, presenta abitazioni con giardini di maggiore estensione. Quest'ultimo è collegato mediante l'antico ponte a sette archi ed uno di recente costruzione al quartiere musulmano di Mangalem.

Fig. 2. La città di Berat: alcuni esempi del rilievo strumentale eseguito tramite Ryobi e Disegno della Pianta quota I,50 m della Chiesa dei Santi Costantino ed Elena nel quartiere Kala.
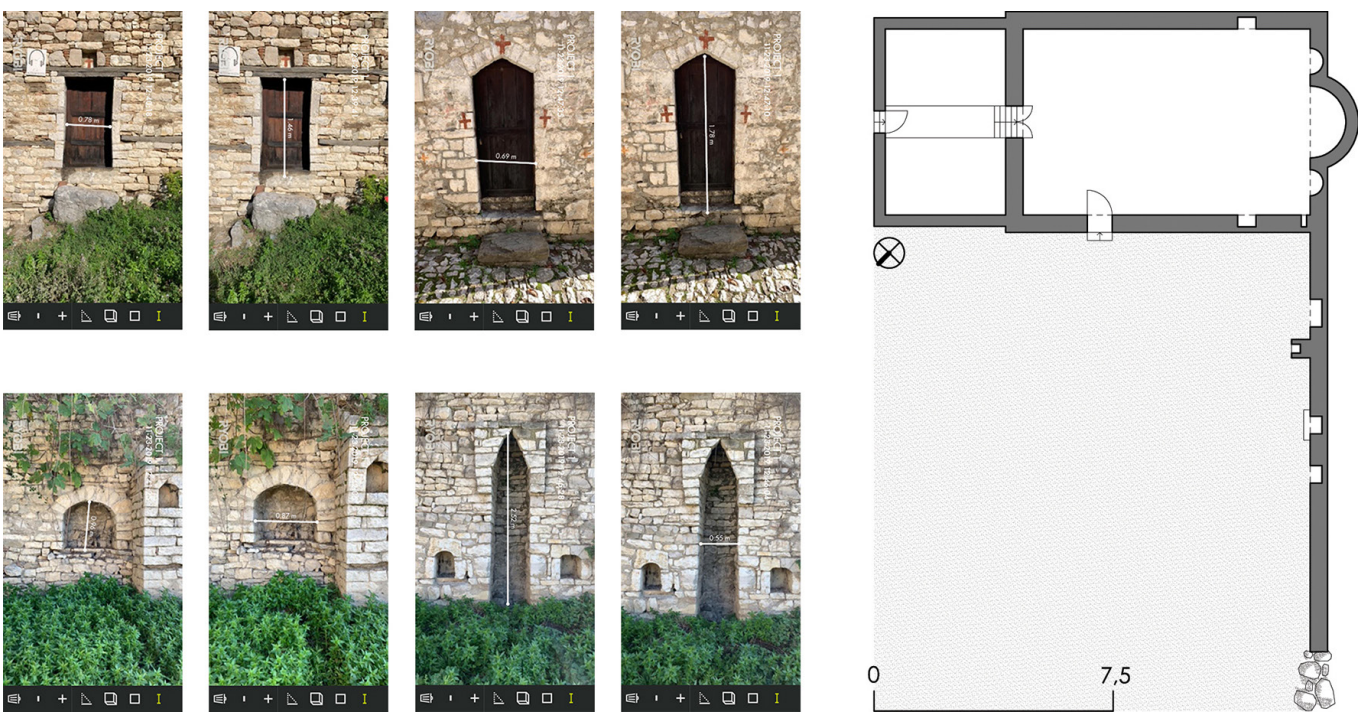

\section{Il disegno delle architetture religiose di Berat}

L'indagine si pone come un possibile esempio metodologico per la gestione e l'analisi delle informazioni acquisite attraverso il rilievo e la loro restituzione grafica. L'obiettivo, dunque, è quello di ricomporre digitalmente le strutture religiose analizzate, offrendo la possibilità di poter fruire virtualmente di tutti gli aspetti materici, formali e dimensionali di cui sono costituite. A tal proposito, l'esistenza di modellatori tridimensionali in grado di consentire la restituzione di organismi complessi e tecniche di fotogrammetria digitale capaci di ricostruire l'aspetto esteriore dell'organismo architettonico hanno favorito la realizzazione della presente ricerca. Tali software sono stati di grande supporto in quanto hanno consentito di codificare, decodificare ed archiviare le informazioni acquisite con l'obiettivo di condividere i dati elaborati per la risoluzione di eventuali problemi di tutela e valorizzazione, presenti e futuri, dei manufatti architettonici analizzati. La conoscenza preventiva, infatti, è la strada che permette di mantenere vivo il patrimonio storico ed architettonico analizzato e quello diffuso, nel quale è possibile rintracciare le identità culturali di una società. Conoscere un'architettura, ed in particolare un bene di interesse storico culturale risulta fondamentale per un'opera finalizzata alla conservazione del bene stesso e per un qualsiasi intervento di valorizzazione [Parrinello $20 \mathrm{ll}$ ]. A tal fine, sono state individuate ed analizzate una serie di nozioni storico-archivistiche che hanno consentito un primo approccio con i manufatti analizzati e, al tempo stesso, di evidenziare le qualità che insieme alle finalità del rilievo consentono di indirizzare la scelta della metodologia di studio o di intervento maggiormente idonea. Nelle fonti d'archivio e iconografiche, è stata ritrovata una planimetria della città trasformata da cartacea a digitale al fine di individuare la posizione delle strutture religiose analizzate confrontandone i dati con l'attuale configurazione (fig. I). 
Fig. 3. La città di Berat: elaborazione della nuvola di punti della Chiesa dei Santi Costantino ed Elen nel quartiere Kala.

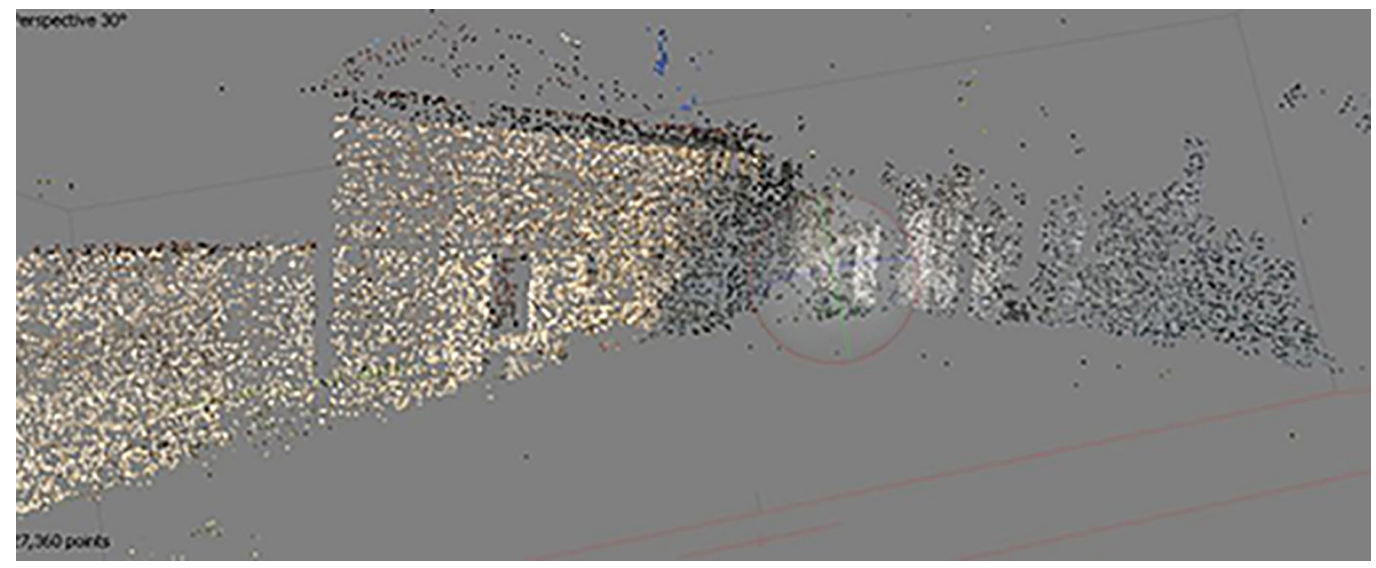

Successivamente, è stata svolta una campagna di rilevamento per ciascuna struttura religiosa analizzata con l'obiettivo di restituire graficamente i dati acquisiti. A tal proposito, il modello digitale può essere considerato come "un vasto, ordinato sistema conoscitivo di informazioni spaziali, modificabile ed implementabile nel tempo" [Gaiani, Alessandri 1999]. Conseguentemente, la scelta dell'approccio, della metodologia e degli strumenti maggiormente idonei è una questione che richiede l'analisi di più parametri. Nel caso oggetto di indagine, si è rivelato utile l'uso del rilievo fotogrammetrico, realizzato attraverso strumenti di misura passivi, ovvero le macchine fotografiche, che consentono di ricavare le coordinate degli oggetti rilevati unicamente tramite le informazioni contenute nelle immagini. In primo luogo, è stato svolto il rilievo delle strutture religiose analizzate con l'obiettivo di ricavare i dati metrici atti al corretto dimensionamento del modello virtuale. Per la creazione di quest'ultimo, mediante immagini, è necessario elaborare una campagna di rilievo capace non solo di acquisire dati relativi alle superfici ma anche quel complesso di algoritmi che consentono di trasformare i dati raccolti in coordinate o misure da poter visualizzare ed analizzare.

A seguito di queste riflessioni, tra le tecniche di rilievo esistenti per i manufatti architettonici analizzati, sono stati scelti il rilievo strumentale e quello fotogrammetrico. Nel primo caso è stato utilizzato lo strumento Ryoby, ovvero un metro laser che consente di prelevare ampie distanze e di riportarle in maniera diretta su supporto fotografico ottenuto mediante l'uso di smartphone o tablet. La prima architettura ad essere analizzata è stata la Chiesa ortodossa dei Santi Costantino ed Elena (fig. 2), una cappella a navata singola il cui volume è stato adattato alla conformazione delle abitazioni circostanti. La chiesa è preceduta da un giardino ed è composta da un altare e da un'abside semicircolare. Un'iscrizione su una pietra posta all'esterno attesta che la chiesa è stata costruita nel I639. Le misure ottenute tramite rilievo strumentale sono state poi riportate all'interno del software utilizzato per la realizzazione del modello virtuale, al fine di ottenere un risultato quanto più possibile fedele alla realtà. Nel caso della fotogrammetria, invece, lo strumento utilizzato è la macchina fotografica e le misure sono state prelevate individuando gli stessi elementi caratteristici su due o più fotogrammi ripresi da differenti punti di vista e ottenuti attraverso la cosiddetta fotogrammetria dei vicini o rangephotogrammetry. Altra caratteristica per la quale è stata scelta questa tecnica di rilievo risiede nel fatto che la fotogrammetria consente di ottenere dei risultati di grande precisione senza necessità di attrezzature particolarmente sofisticate. Ulteriore

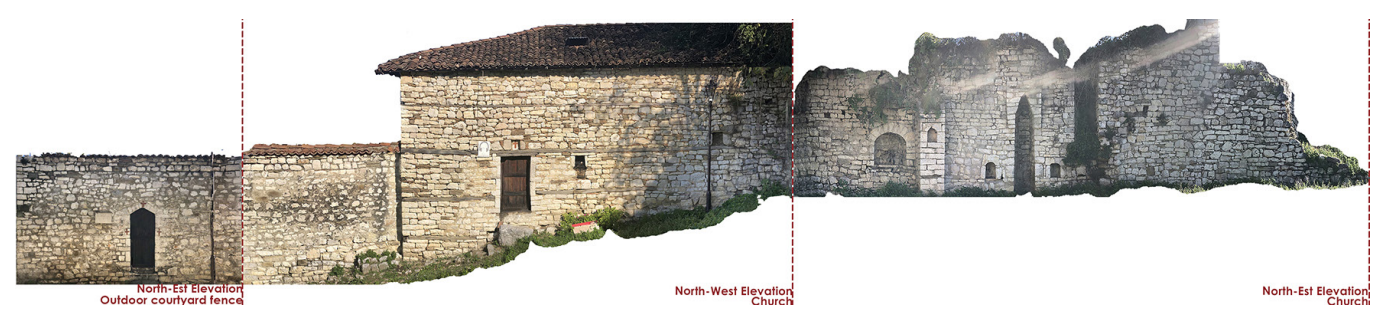
Norn-West Elevation
Fig. 4. La città di Berat: Fotopiano di tre prospett della Chiesa del Santi quartiere Kala. 
Fig. 5. La città di Berat: alcuni esempi del rilievo strumentale eseguito tramite strumento Ryob della Moschea Bianca ne quartiere Ka
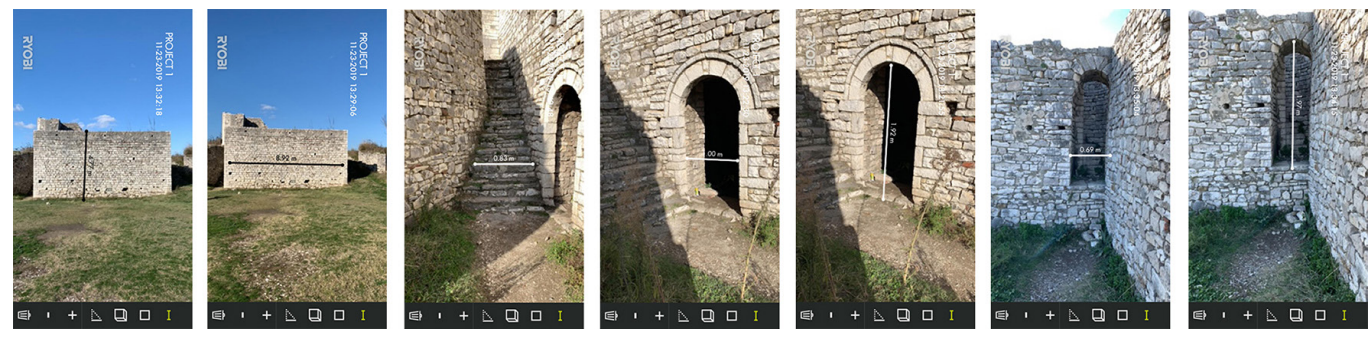

Fig. 6. La città di Berat: elaborazione della nuvola di punti della Moschea Bianca nel quartiere Kala.

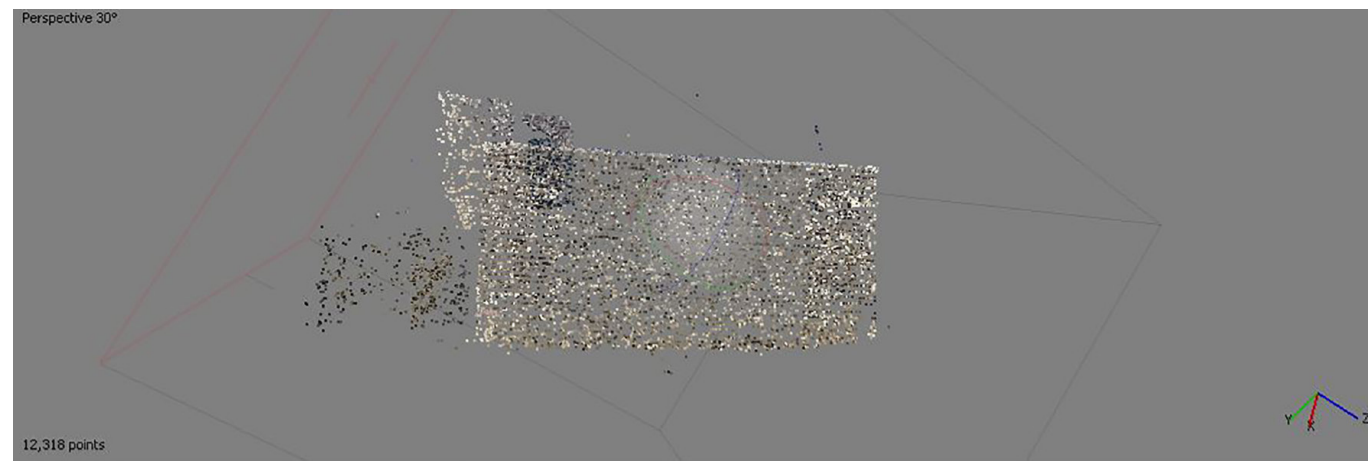

Fig. 7. La città di Berat: fotopiano del prospetto Ovest della Moschea Bianca nel quartiere Kala

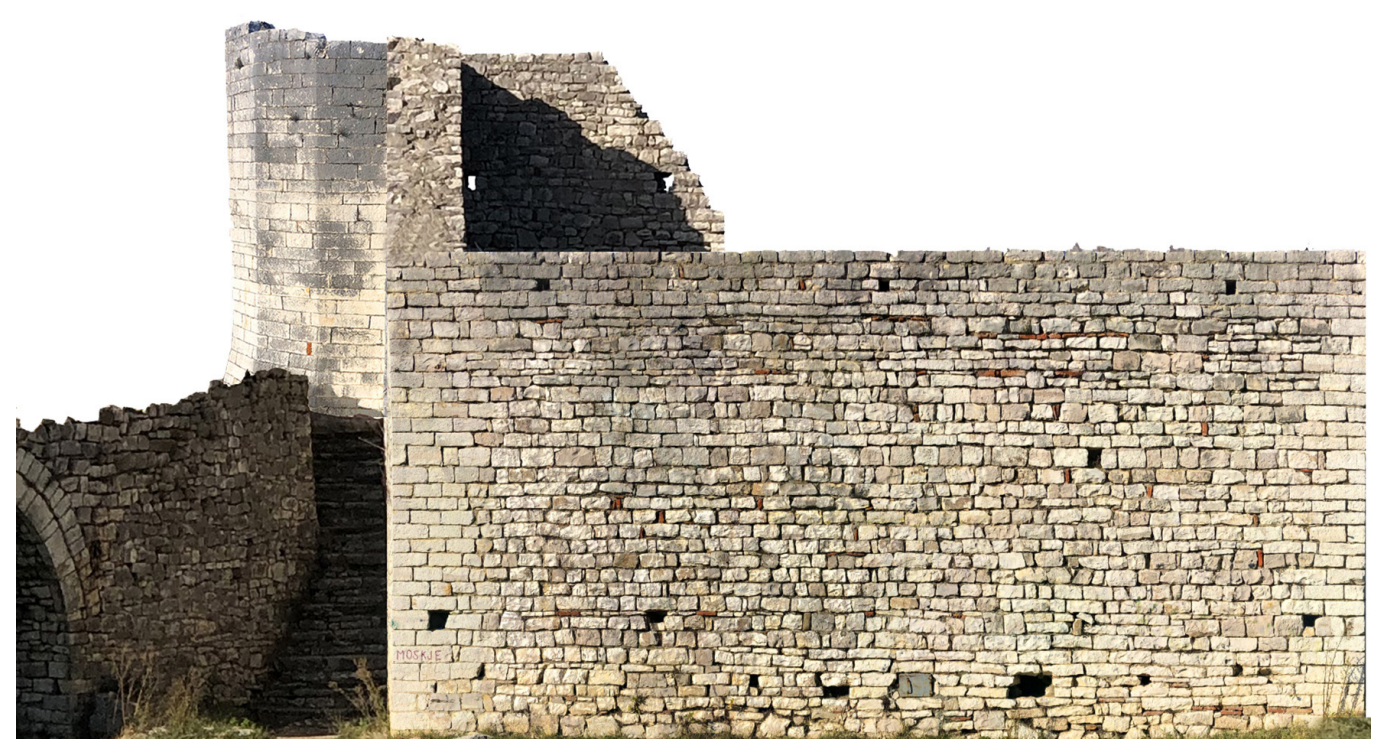

Fig. 8. La città di Berat: nuvola di punti della

Moschea Rossa nel quartiere Kala.

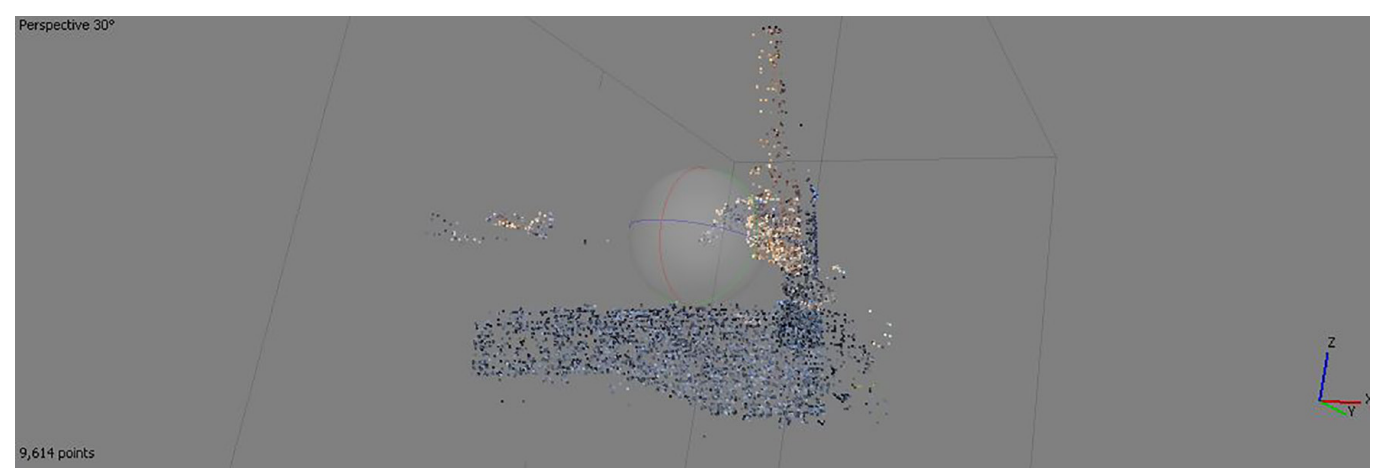


Fig. 9. La città di Berat: alcuni esempi del rilievo strumentale eseguito tramite strumento Ryobi e Disegno della Pranta quota 8,00 m della Moschea degli Scapoli ne quartiere Mangalem.
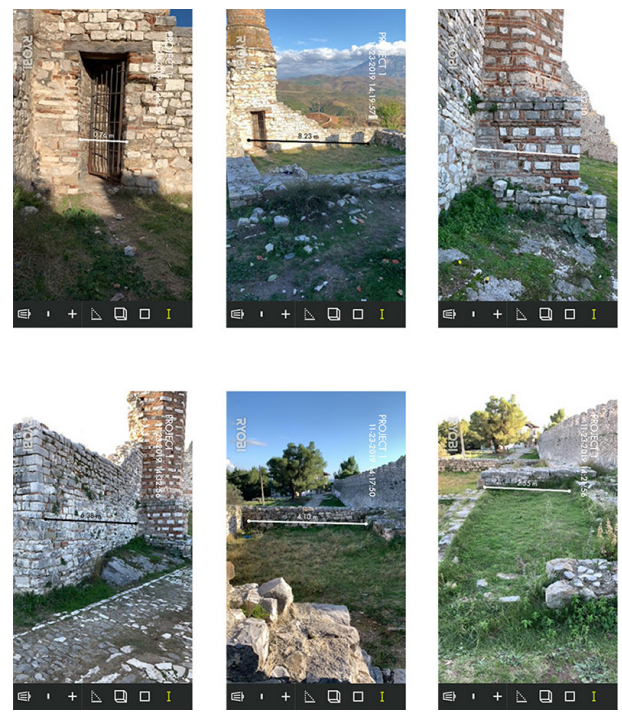

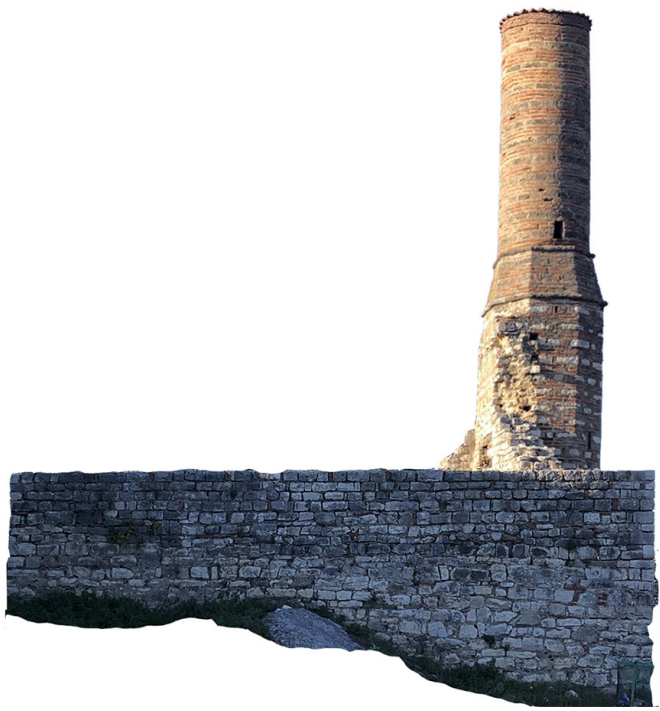

vantaggio di questa tecnica è l'ottenimento di modelli già perfettamente texturizzati. A tal fine è stata necessaria la fase preventiva che ha interessato l'individuazione della posizione e dell'orientamento della camera rispetto all'oggetto da rilevare e la posizione di ogni immagine rispetto alla precedente attraverso il riconoscimento di coppie di punti omologhi; a tal proposito, sono state acquisite immagini fotografiche in modo da poter sovrapporre coppie di scansioni adiacenti per il 30-40\% della superficie totale al fine di garantire un corretto funzionamento della successiva fase di allineamento. Infine, è stato costruito il modello geometrico servendosi di software in grado di trasformare le coordinate e i dati acquisiti in nuvole di punti e modelli virtuali (fig. 3). Infine, una volta elaborato il modello tridimensionale sono state esportate dal software delle immagini bidimensionali al fine di elaborare alcuni fotogrammi bidimensionali delle strutture analizzate (fig. 4). I dati ottenuti attraverso il rilievo strumentale sono stati confrontati con i dati metrici acquisiti durante la campagna di rilevamento al fine di verificare l'accuratezza della restituzione grafica dei software digitali utilizzati. A tal proposito, i valori acquisiti attraverso il rilievo risultano quasi del tutto invariati all'interno dei modelli digitali ottenuti e, conseguentemente, la fotogrammetria è risultata la strada migliore da perseguire per processare le informazioni acquisite di ciascun manufatto architettonico analizzato.
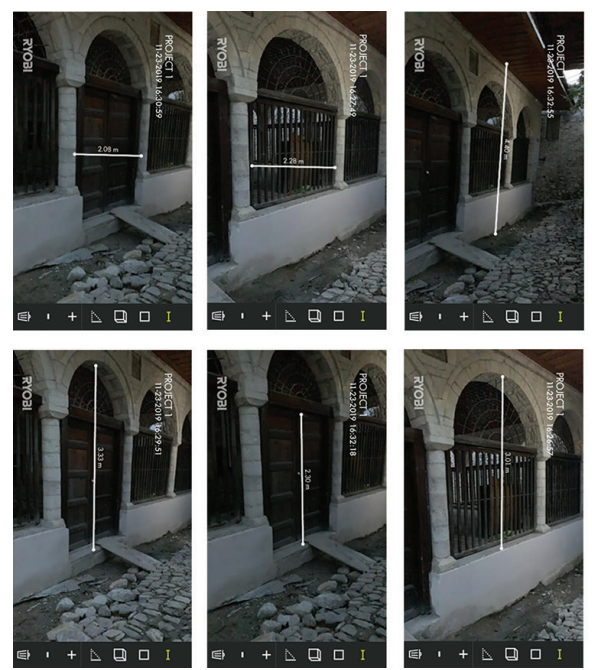

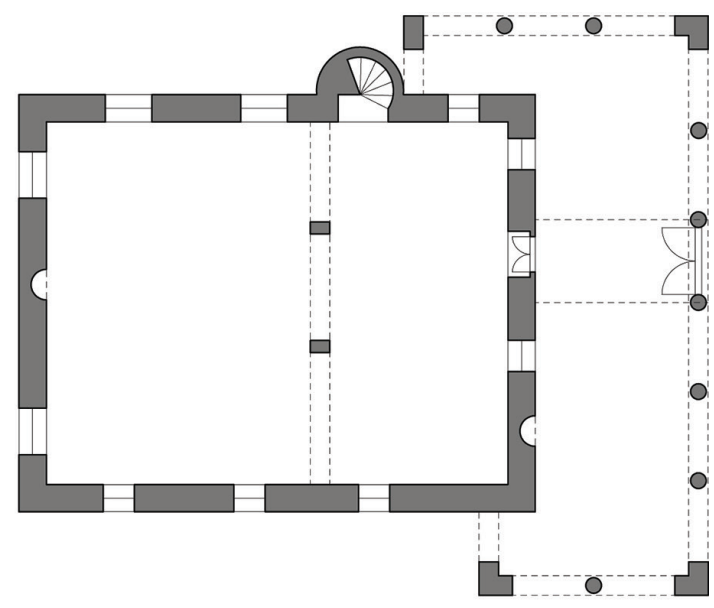

7,5 
Fig. I I. La città di Berat: disegno del prospetto Sud-Est e prospetto Nord-Ovest della Moschea degli Scapoli ne quartiere Mangalem
Analogo procedimento di conoscenza è stato elaborato per la moschea Rossa, la moschea Bianca e la moschea degli Scapoli. La moschea Bianca (figg. 5-7), situata all'interno delle mura del castello di Kala, è un manufatto religioso destinato al culto islamico risalente al XV secolo. Originariamente destinata alla guarnigione turca, ciò che oggi resta fa ipotizzare la presenza di minareto che un tempo svettava tra tutti gli edifici del quartiere.

La moschea Rossa (figg. 8,9), invece, è un edificio religioso destinato al culto islamico considerata un esempio architettonico di notevole interesse. Costruita sotto il regno di Bayezid II nel XVI secolo poco dopo la conquista di Berat da parte degli Ottomani nel |4I7, oggi ne restano soltanto le fondamenta ed il pilastro principale del minareto.

La moschea degli Scapoli (figg. I0, I I) nel quartiere musulmano di Mangalem, infine, rappresenta uno degli esempi più significativi dell'architettura islamica. Costruita alla fine del XVIII secolo, da un punto di vista tipologico segue il modello della sala con portico ad archi all'ingresso. Successivamente, nel I 827, furono eseguiti alcuni lavori che hanno portato alla ricostruzione parziale del minareto e alla decorazione delle facciate interne ed esterne attraverso alcuni affreschi.
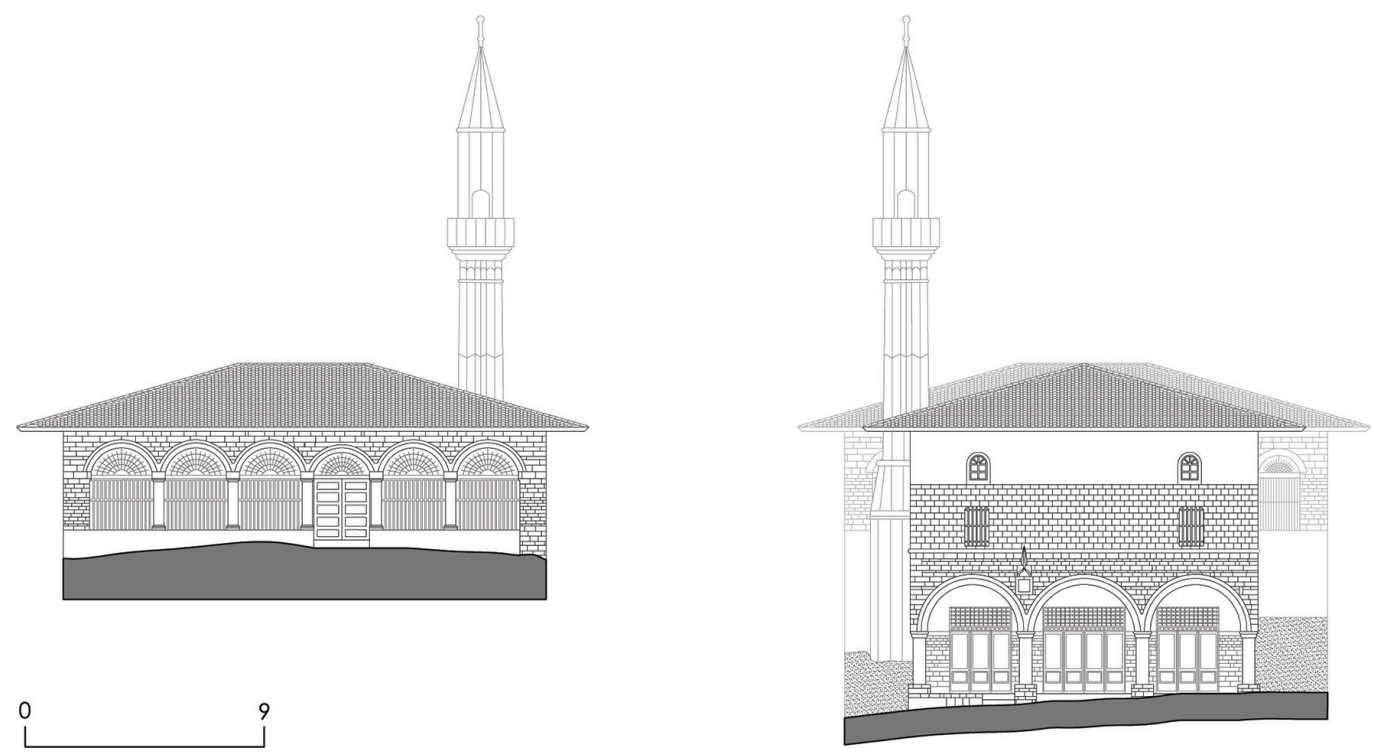

\section{Conclusioni}

L'indagine svolta si pone come un possibile esempio metodologico di lettura delle architetture religiose della città di Berat volto all'elaborazione di un archivio digitale contenente una serie di informazioni acquisite attraverso il rilievo, da quelle materiche a quelle costruttive e da quelle dimensionali a quelle formali, delle architetture religiose studiate. L'obiettivo principale è stato quello di elaborare un modello pronto ad essere utilizzato come materiale per la progettazione architettonica futura volta alla conservazione e alla valorizzazione dei manufatti architettonici analizzati. A tal proposito, la costruzione di modelli informativi digitali per la restituzione di organismi complessi e tecniche di fotogrammetria digitale capaci di ricostruire l'aspetto esteriore delle architetture analizzate hanno favorito la realizzazione della presente ricerca. Le contemporanee applicazioni software, infatti, hanno consentito di controllare in maniera diretta i dati acquisiti attraverso il rilievo e di elaborare veri e propri archivi digitali che potranno restare aperti per continui aggiornamenti, monitoraggi e verifiche, ed implementabili con eventuali ulteriori dati da fonti archeologiche, storiche e documentarie che potrebbero mutare nel tempo. Attraverso gli studi proposti si intende offrire strumenti interpretativi ed operativi capaci di prevenire e contrastare le problematiche derivanti dalla valorizzazione e dalla conservazione con l'obiettivo di potenziare la conoscenza collettiva del patrimonio culturale del territorio albanese, nella maggior parte dei casi dimenticato e non valorizzato [4]. 


\section{Note}

[I] Dal Dizionario Treccani, ad vocem.

[2] Dal Dizionario Treccani, ad vocem.

[3] La città di Berat è stata dichiarata dall'Unesco come "raro esempio di città ottomana ben conservata, nonché fulgido modello di pacifica convivenza di religioni diverse nei secoli passati".

[4] II presente contributo è stato realizzato grazie al finanziamento Valere 20।9 dell'Università degli Studi della Campania "Luigi Vanvitelli".

\section{Riferimenti bibliografici}

AA.W. ( 1917). Itinerari Albanesi ( 1892-1902), con uno sguardo generale all'Albania e alle sue comunicazioni stradali. Roma: Reale Società Geografica italiana.

Benedettini Benedetto, Gaiani Marco, Remondino Fabio (20 I0). Modelli digitali 3d in archeologia: il caso di Pompei. Pisa: Edizioni della Normale.

Bertocci Stefano, Bini Marco (2004). Castelli di pietre. Aspetti formali e materiali dei castelli crociati nell'area di Petra in Tansgiordania. Firenze: Edizioni Polistampa.

Bertocci Stefano, Parrinello Sandro (20 I 5). Digital Survey and Documentation of the Archeological and Architectural sites. Firenze: Edifir Edizioni.

Corniello Luigi, Maliqari Andrea (2016). The Unesco site of Berat in Albania: the protection and the enhancement of the heritage. In Gambardella Carmine (a cura di). World Heritage and degradation, XIV Forum Internazionale di Studi Le vie dei Mercanti. Capri 16-18 giugno 2016. Napoli: La scuola di Pitagora editrice, pp. 1708-1717.

Corniello Luigi, Maiolino Francesco (20 I4). II rilievo come strumento di conoscenza. L'architettura sacra di Berat. In Giandebiaggi Paolo, Vernizzi Chiara (a cura di). Italian survey \& International experience. Atti del $36^{\circ}$ Convegno dei Docenti delle discipline della Rappresentazione. Parma 18-20 settembre 20 |4. Roma: Gangemi Editore.

Docci Mario, Gaiani Marco, Maestri Diego (201 I). Scienza del Disegno. Novara: Città Studi Edizioni.

Fatta Francesca (20 I 6). La rappresentazione del patrimonio culturale tra finalità e innovazione. In Cicalò Enrico, Solci Margherita (a cura di). Modelli matematici e grafici per una ridefinizione delle prospettive/Mathematical and graphical models for a redefinition of perspectives. Roma: Gangemi Editore.

Gaiani Marco, Alessandri Claudio (1999). The Atrium of St. Mary Abbey in Pomposa: a hypermedial 3D network database. In AA.W. Eurographics '99- short papers and demo proceedings. Roma: Gangemi Editore, pp. 96-99

Galanti Arturo (I90 I). L'Albania: notizie geografiche, etnografiche e storiche. Roma: Società Ed. Dante Alighieri

Giordano Paolo (20 I4). Ridisegno, rilievo e riconfigurazione dell'Albergo dei Poveri di Napoli. Roma: Gangemi Editore.

Parrinello Sandro (20 I I). L'esperienza di rilievo e documentazione dell'Abbazia di Vallombrosa. In Bertocci Stefano, Parrinello Sandro ( acura di). Architettura Eremitica. Sistemi progettuali e Paesaggi culturali. Firenze: Edifir Edizioni, pp. I7-31.

\section{Autore}

Adriana Trematerra, Università degli Studi della Campania “Luigi Vanvitelli”, adriana.trematerra@unicampania.it

Per citare questo capitolo:Trematerra Adriana (2020). Reti e nodi nella città di Berat in Albania/Networks and connections in the city of Berat in Albania. In Arena A., Arena M., Brandolino R.G., Colistra D., Ginex G., Mediati D., Nucifora S., Raffa P. (a cura di). Connettere. Un disegno per annodare e tessere. Atti del $42^{\circ}$ Convegno Internazionale dei Docenti delle Discipline della Rappresentazione/Connecting. Drawing for weaving relationships. Proceedings of the 42th International Conference of Representation Disciplines Teachers. Milano: FrancoAngeli, pp. 2787-2802. 


\title{
Networks and Connections in the City of Berat in Albania
}

\author{
Adriana Trematerra
}

\section{Abstract}

The contribution proposes the study of the religious architecture of the city of Berat in Albania, a World Heritage Site since 2008 and a rare example of the coexistence of multiple faiths, and is part of a broader knowledge focused on the study of religious complexes located in the geographical area of the Balkans. Specifically, will be analyzed the Orthodox Church of Saints Constantine and Helen, the Red Mosque, the White Mosque and the Mosque of the Bachelors, the latter destined for Islamic cult. The aim of this survey is to describe and illustrate the architectural artifacts analyzed through architectural drawing, with the aim of providing a path of knowledge capable of triggering reflections on the critical conservation and enhancement of religious cult in order to protect the urban and landscape heritage handed down over the centuries by different cultures that have defined the current configurations of the artifacts analyzed.

Keywords

drawing, survey, knowledge, religion, architecture.

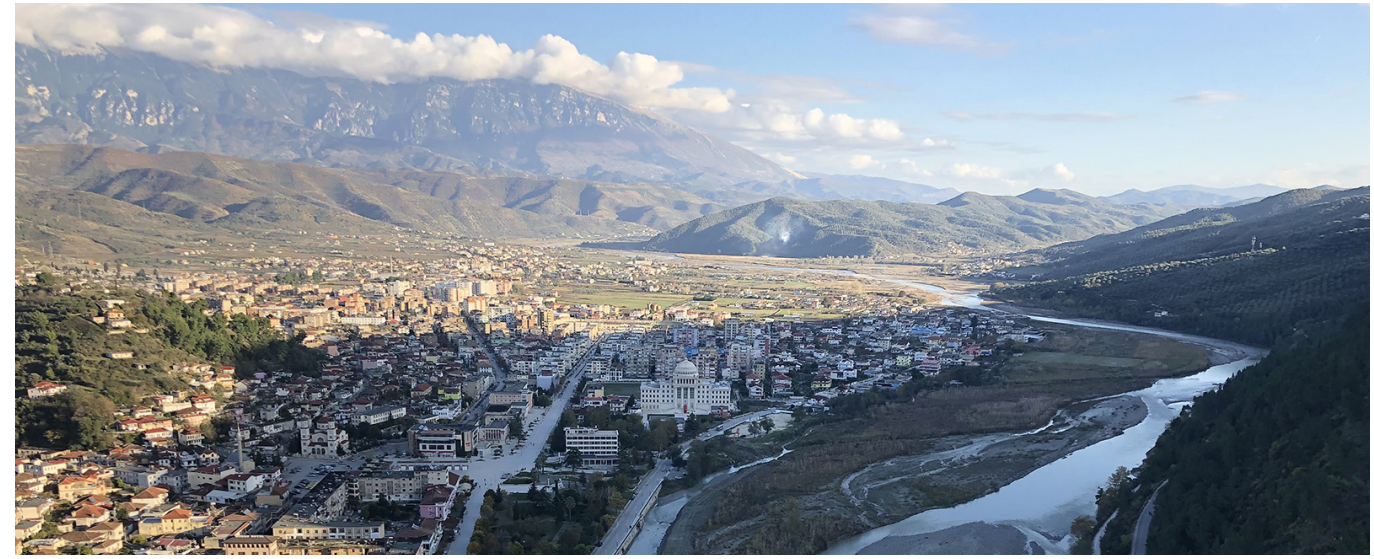




\section{Introduction}

The research takes place, first of all, through the analysis of the term Connect, that is "to join, to knot [...] to create a connection between elements", "to relate two or more facts, concepts" [I] , with the aim of identifying a synonym with which to give life to the present research. Among the latter the term to relate has been identified, that is "to relate, to compare a situation, a quantity with another" [2]. The city of Berat has always been considered the landscape of the secular cohabitation of different faiths: Catholic and Orthodox Christians, Muslims and bektaschi who, over the centuries, have demonstrated an extraordinary example of religious cohabitation and mutual respect [3]. A place where there is a deep relationship, and therefore a deep connection, between different religious cultures that have determined the creation of different architectural structures that have coexisted harmoniously on the same territory for centuries. The city of Berat, included in 2008 in the list of World Heritage Sites, still retains a total of 42 religious, Christian and Muslim buildings and is divided into 3 districts: Kala, within the walls of the old fortress, at the top of the hill on the left bank of the river Osum, Mangalem, along the hill and towards the river, Gorica, the Christian quarter, on the flat, beyond the Osum river nestled between the mountains. Kala, the most varied of the districts, with about thirty churches and the remains of two mosques, preserves almost intact its character, with streets defined by the boundary walls of the gardens and those of the houses with overhanging, wooden and widely glazed parts, and roofs covered with red tiles with a slight slope. The district, $187 \mathrm{~m}$ above sea level with an area of 9.6 hectares, consists of the castle surrounded by imposing walls of Hellenistic type and subsequent medieval remodeling with 24 towers of different shapes and sizes. The castle's basements are also preserved, covered by brick barrel vaults supported by powerful columns 10 meters high. Of the numerous religious structures present, three have been analysed:The Church of Saints Constantine and Helen, the remains of the White Mosque and those of the Red Mosque. Particularly compact is, instead, the Muslim quarter of Mangalem, initially used as a bazaar with residences of merchants and craftsmen, now consisting mainly of houses, which extends on the steep slope forming a triangular figure on top of which is the castle. The main characteristic of the village is the 1001 windows of

Fig. I. The city of Berat: general plan with the identification of the Church of Saints Constantine and Helen, the White Mosque, the Red Mosque and the Bachelor Mosque.
1. Chiesa dei Santi Costantino ed Elena 2. Moschea Bianca

3. Moschea Rossa

4. Moschea degli Scapoli

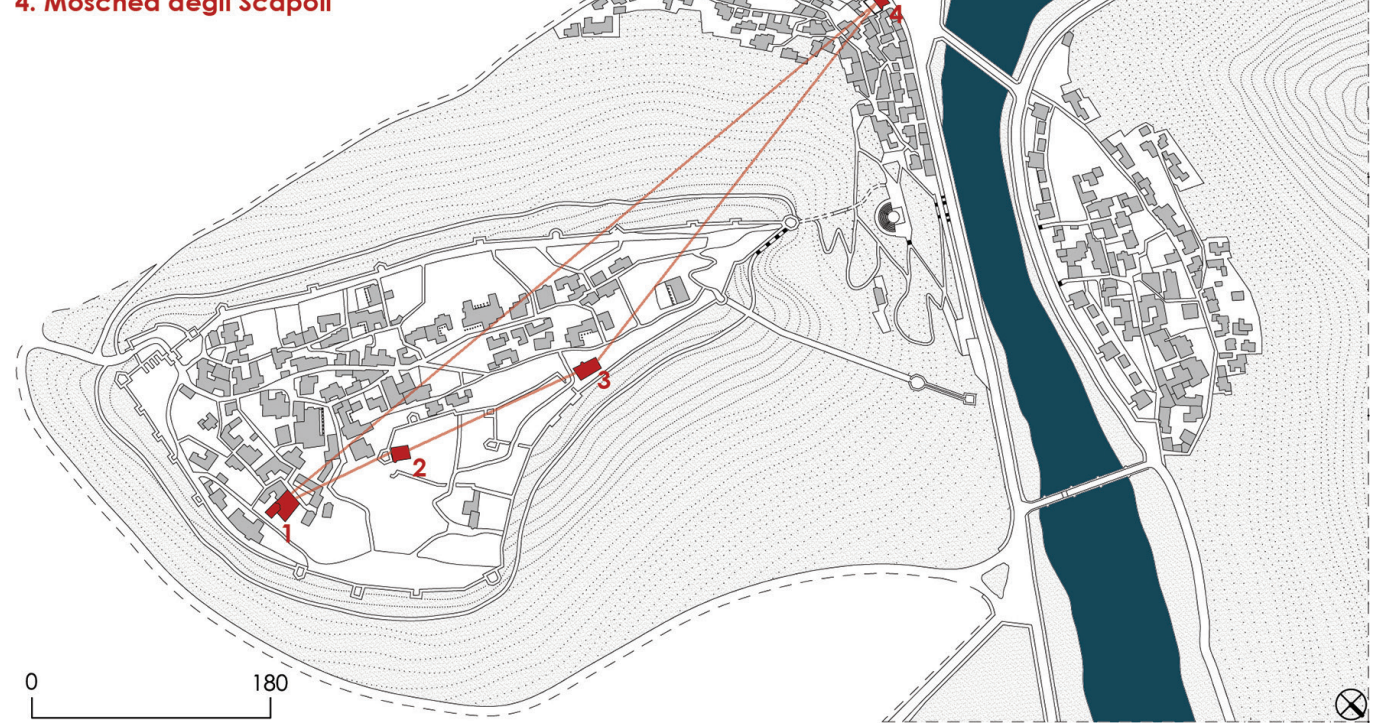


the houses and public structures. There are some mosques among which the Mosque of the Scapoli has been analyzed. Finally, the Orthodox Christian district of Gorica, developed in the 16th century on the right bank of the river Osum, has houses with larger gardens. The latter is connected by the old bridge with 7 arches and one recently built to the Muslim quarter of Mangalem.

Fig. 2. The city of Berat: some examples of the instrumental survey carried out through Ryobi and Drawing of the Plan of the Church of Saints Constantine and Helen in the Kala district.
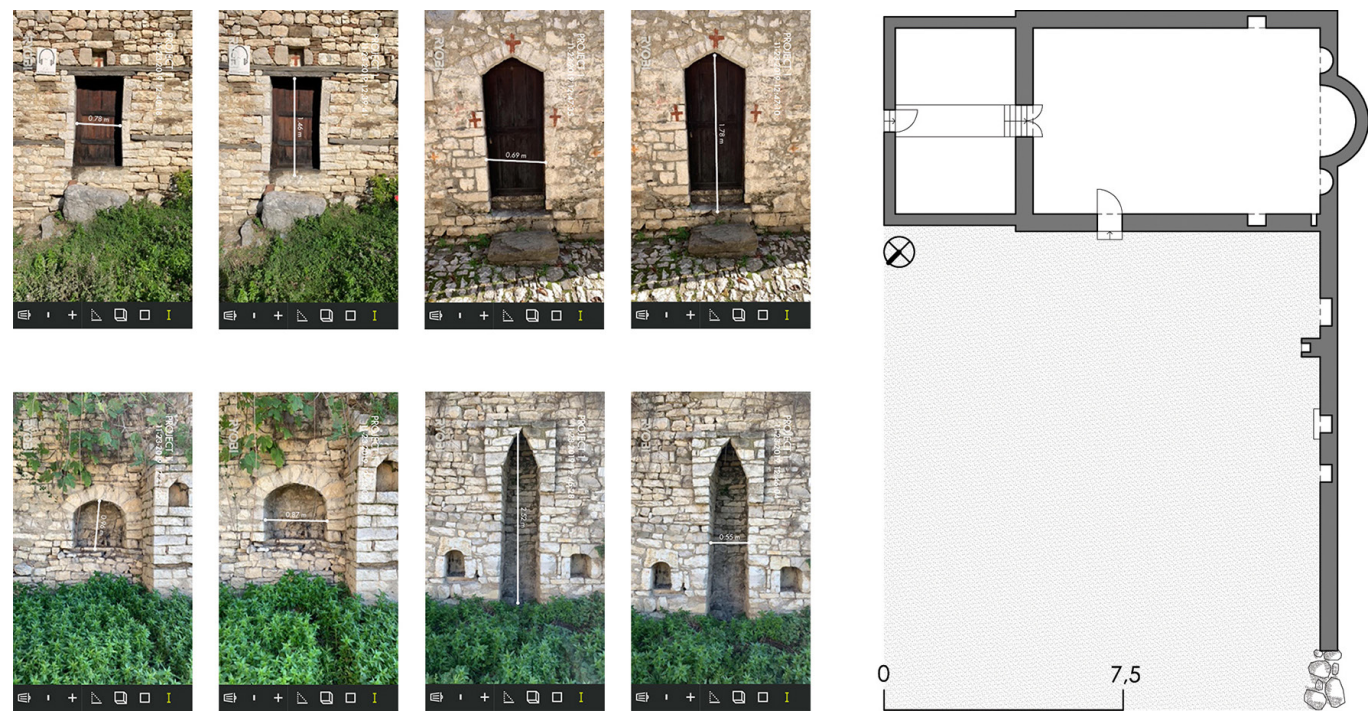

\section{The drawing of the religious architecture of Berat}

The research is a possible methodological example for the management and analysis of the information acquired through the survey and its graphic restitution. The objective, therefore, is to digitally recompose the religious structures analyzed, offering the possibility of being able to enjoy virtually all the material, formal and dimensional aspects of which they are made up. In this regard, the existence of three-dimensional modelers able to allow the restitution of complex organisms and digital photogrammetry techniques capable of reconstructing the external aspect of the architectural organism have favored the realization of this research. These software have been of great support as they have allowed to encode, decode and archive the information acquired with the aim of sharing the data processed for the resolution of any problems of protection and enhancement, present and future, of the architectural artifacts analyzed. Preventive knowledge, in fact, is the way to keep alive the historical and architectural heritage analyzed and the widespread one, in which it is possible to trace the cultural identities of a society. Knowing an architecture, and in particular an asset of historical and cultural interest, is fundamental for a work aimed at the preservation of the asset itself and for any enhancement intervention [Parrinello $20 \mathrm{ll}$ ]. To this end, a series of historical-archival notions have been identified and analyzed, which have allowed an initial approach with the artifacts analyzed and, at the same time, to highlight the qualities that, together with the purposes of the survey, allow to direct the choice of the most suitable methodology of study or intervention. In the archive and iconographic sources, a plan of the city has been found, transformed from paper to digital in order to identify the position of the religious structures analysed, comparing the information with their current configuration (fig. I). Subsequently, a survey campaign was carried out for each religious structure 
Fig. 3. The city of Berat: elaboration of the point cloud of the Church of Saints Constantine and

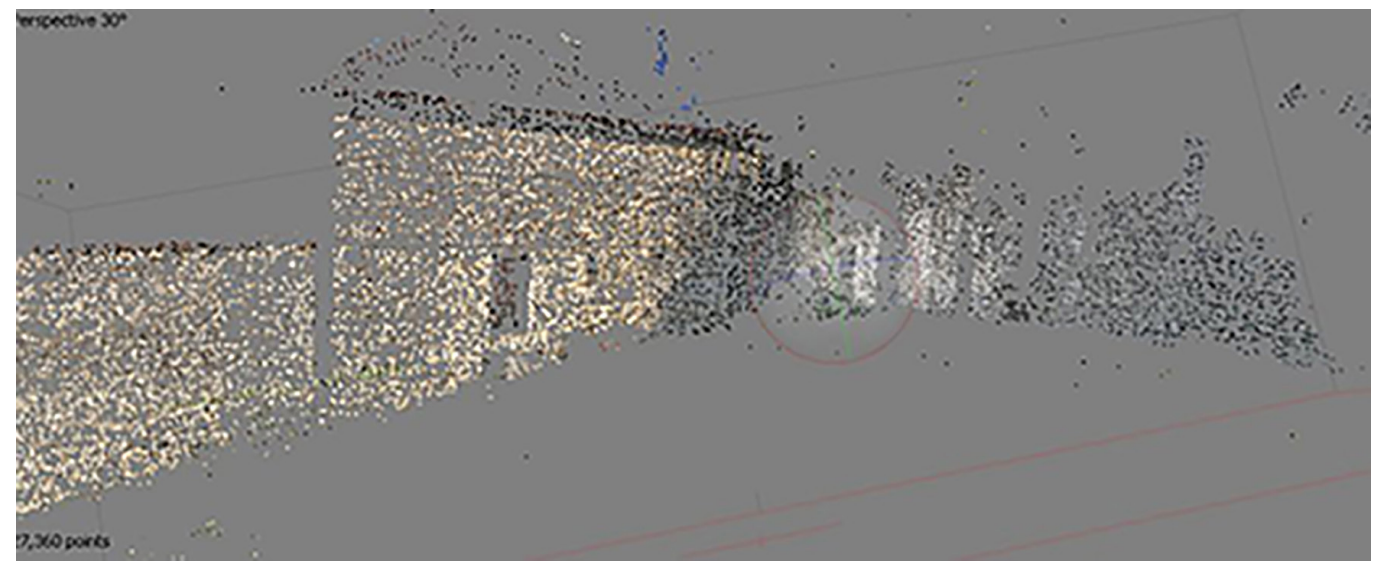

analysed with the aim of graphically reproducing the information acquired. In this regard, the digital model can be considered as "a vast, ordered cognitive system of spatial information, modifiable and implementable over time" [Gaiani, Alessandri 1999]. Consequently, the choice of the most suitable approach, methodology and tools is a matter that requires the analysis of several parameters. In the case under investigation, the use of photogrammetric surveying, realized through passive measuring instruments, that is the cameras, which allow to obtain the coordinates of the detected objects only through the information contained in the images, has proved useful. First of all, the survey of the religious structures analysed was carried out with the aim of obtaining the metric data suitable for the correct dimensioning of the virtual model. For the creation of the latter, through images, it is necessary to elaborate a survey campaign capable not only of acquiring informations about the surfaces but also the complex of algorithms that allow the data collected to be transformed into coordinates or measurements that can be visualized and analyzed. As a result of these reflections, among the existing surveying techniques for the architectural artifacts analyzed, instrumental and photogrammetric surveying were chosen. In the first case the Ryoby tool was used, that is a laser meter that allows you to pick up large distances and bring them directly back on a photographic support obtained through the use of a smartphone or tablet. The first architecture to be analyzed was the Orthodox Church of Saints Constantine and Helen (fig. 2), a single nave chapel whose volume was adapted to the conformation of the surrounding houses. The church is preceded by a garden and consists of an altar and a semicircular apse. An inscription on a stone placed outside attests that the church was built in 1639. The measurements obtained through instrumental survey were then reported inside the software used to create the virtual model, in order to obtain a result as faithful to reality as possible. In the case of photogrammetry, on the other hand, the instrument used is the camera and the measurements were taken by identifying the same characteristic elements on two or more frames taken from different points of view and obtained through the so-called rangephotogrammetry. Another characteristic for which this survey technique was chosen is that the photogrammetry allows to obtain very precise results without the need of particularly sophisticated equipment. A further advantage of this technique is the obtaining of already

Fig. 4. The city of Berat: Photoplan of three elevations of the Church of Saints Constantine and Helen in the Kala district.

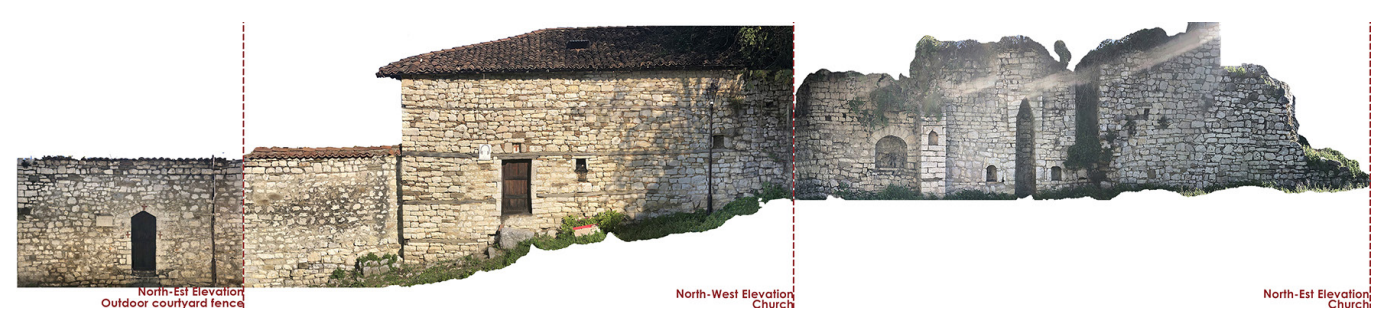


Fig. 5. The city of Berat: some examples of the instrumental survey performed by Ryobi instrument of the White Mosque in the Kala district.
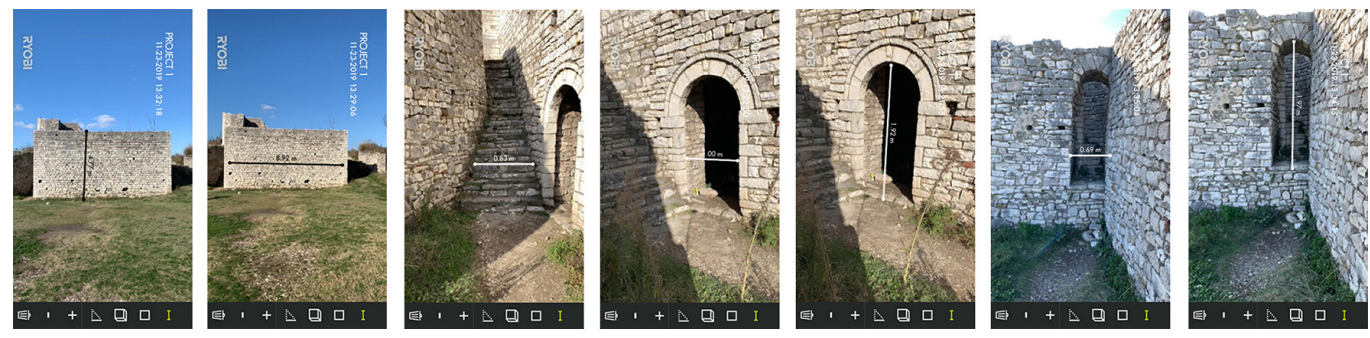

Fig. 6. The city of Berat: elaboration of the points cloud of the White Mosque in the Kala district.

Fig. 7.The city of Berat: photoplan of the West elevation of the White

Mosque in the Kala district.
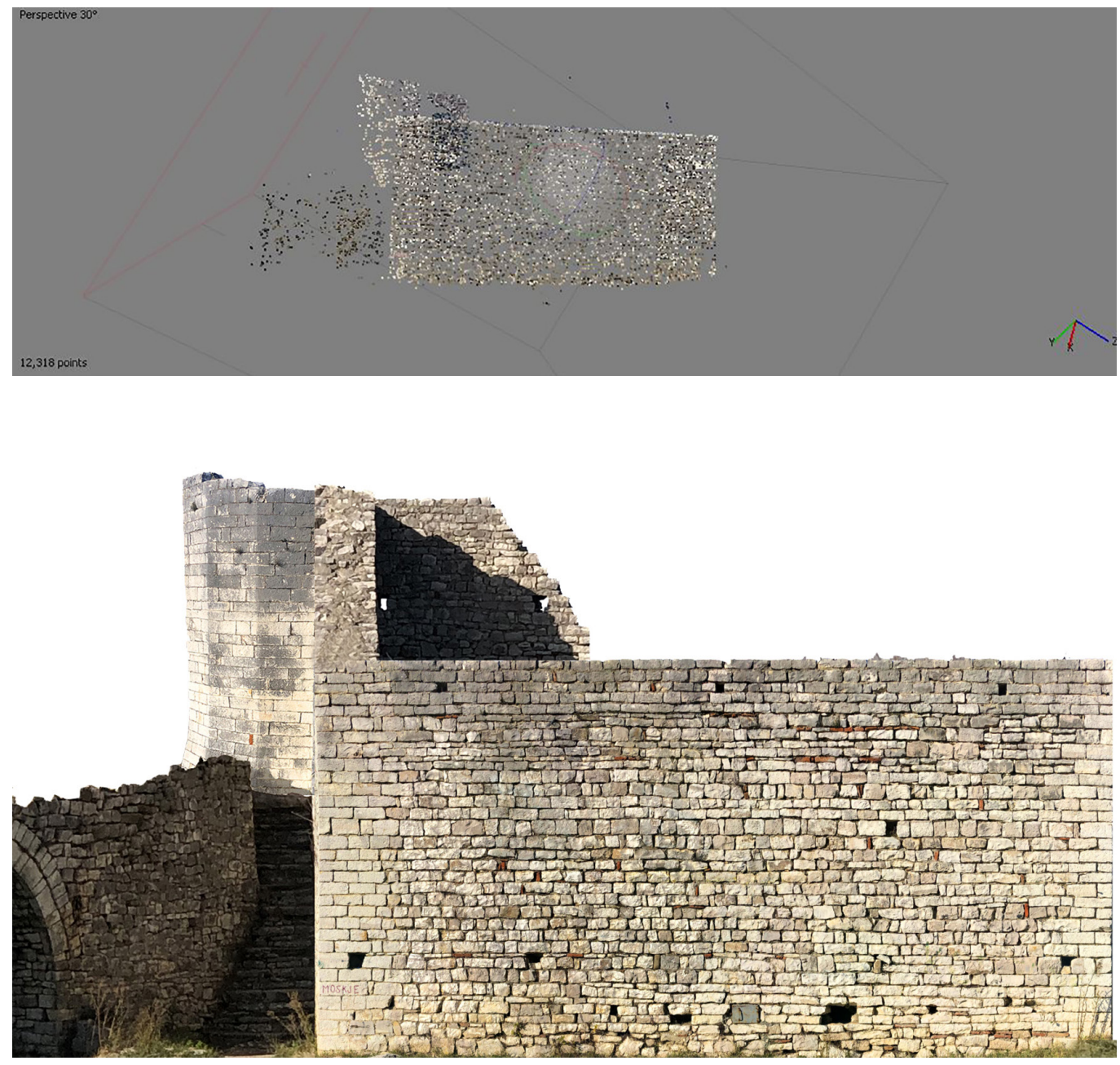

Fig. 8. The city of Berat: points cloud of the Red

Mosque in the Kala

district.

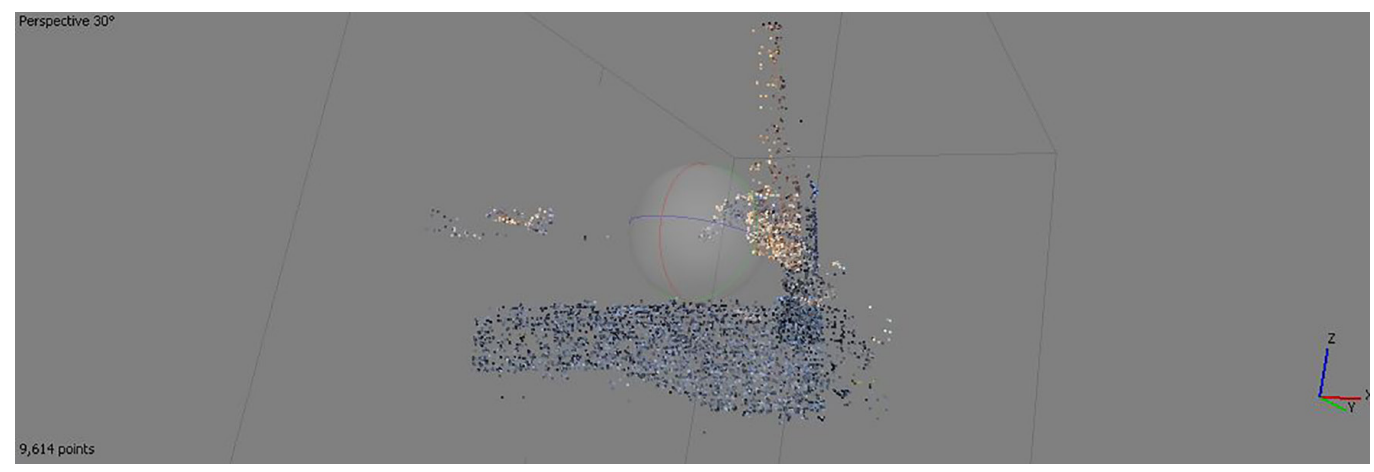


Fig. 9. The city of Berat: some examples of the instrumental survey performed by Ryobi instrument and photoplan of the South elevation of the Red Mosque in the Kala district.
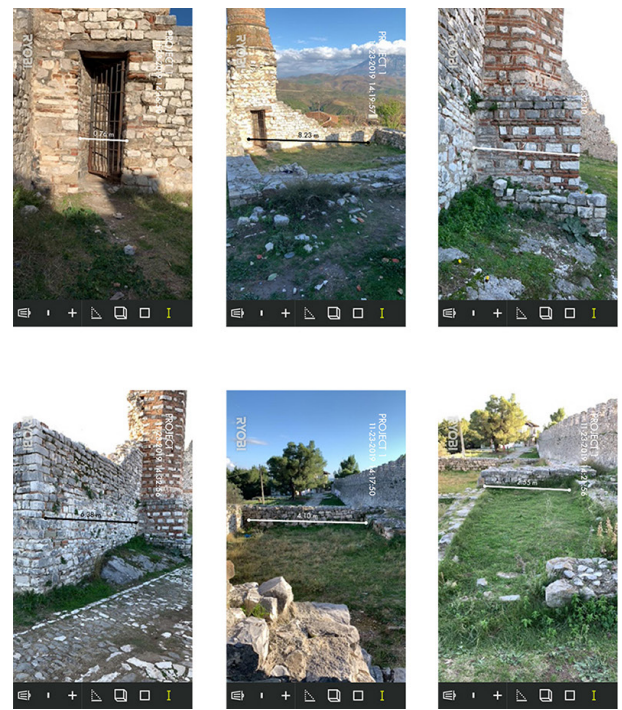

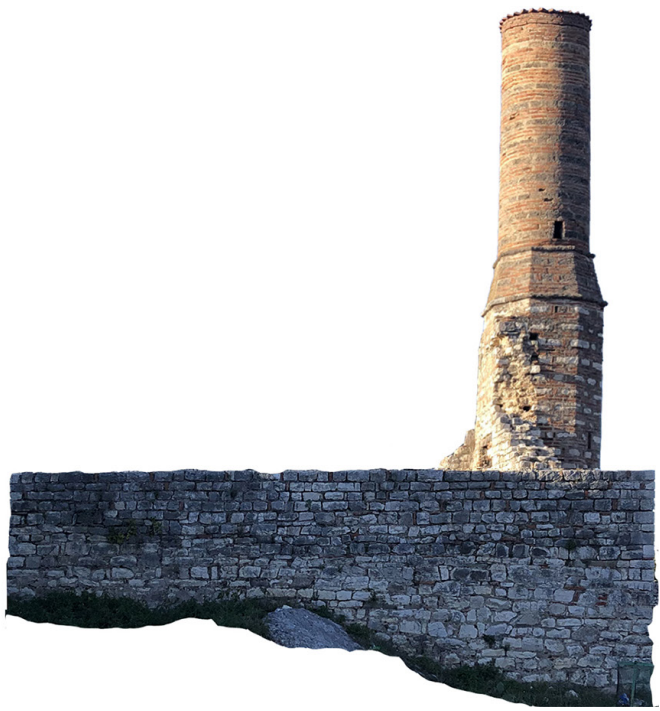

perfectly textured models. For this purpose, a preventive phase was necessary, which involved the identification of the position and orientation of the camera respect to the object to be surveyed and the position of each image respect to the previous one through the recognition of pairs of homologous points; in this regard, photographic images were acquired so as to be able to superimpose pairs of adjacent scans for $30-40 \%$ of the total surface in order to guarantee the correct functioning of the subsequent alignment phase. Finally, the geometric model was constructed using software capable of transforming the coordinates and data acquired into point clouds and virtual models (fig. 3). Finally, once the three-dimensional model was elaborated, two-dimensional images were exported from the software in order to elaborate a photoplan of the analyzed structures (fig. 4). The data obtained through the instrumental survey were compared with the metric data acquired during the survey campaign in order to verify the accuracy of the graphic restitution of the digital software used. In this regard, the values acquired through the survey are almost completely unchanged within the digital models obtained and, consequently, the photogrammetry was the best way to process the acquired information of each architectural artifact analyzed.
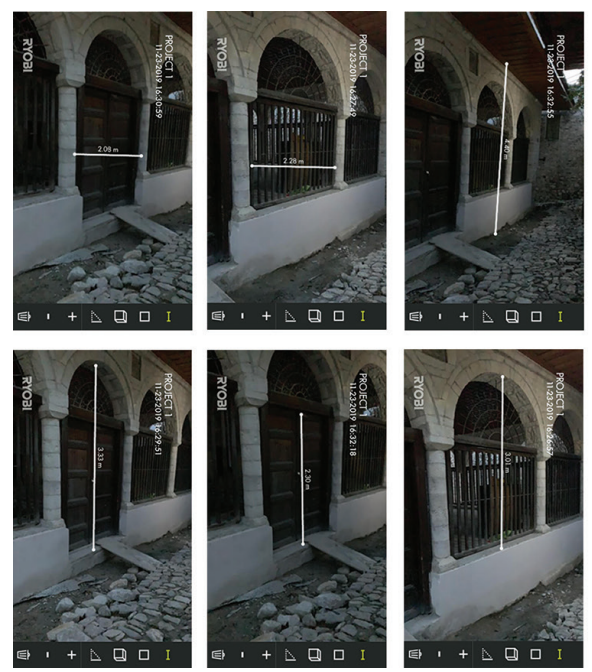

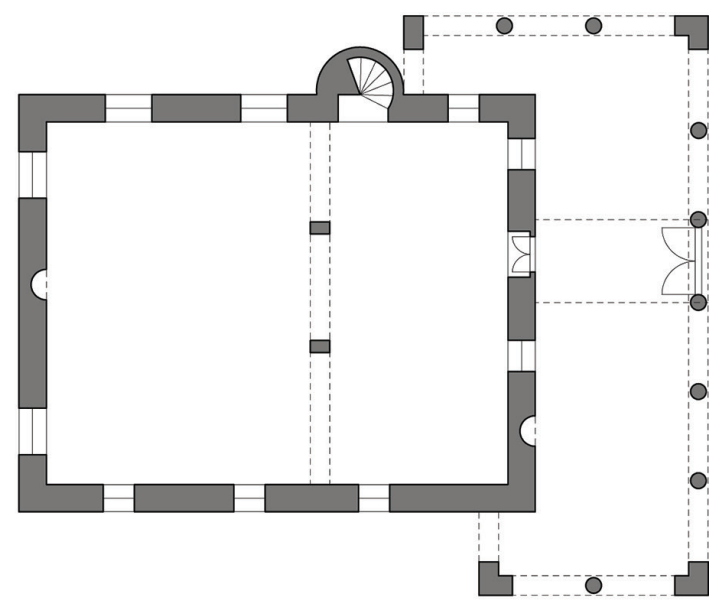

7,5 
Fig. I I.The city of Berat: Drawing of SouthEast and North-West elevations of the Bachelor Mosque in the Mangalem district
A similar knowledge process has been developed for the Red Mosque, the White Mosque and the Bachelor Mosque. The White Mosque (figs. 5-7), located within the walls of Kala Castle, is a religious artefact for Islamic worship dating back to the I5th century. Originally intended for the Turkish garrison, what remains today suggests the presence of a minaret that once stood out among all the buildings in the district.

The Red Mosque (figs. 8, 9), on the other hand, is a religious building intended for Islamic worship and considered an architectural example of considerable interest. Built during the reign of Bayezid II in the I6th century shortly after the Ottomans conquered Berat in 1417, today only the foundations and the main pillar of the minaret remain.

The Mosque of the Bachelors (figs. I0, II) in the Muslim quarter of Mangalem, finally, represents one of the most significant examples of Islamic architecture. Built at the end of the I 8th century, from a typological point of view it follows the model of the hall with arched portico at the entrance. Later, in 1827, some works were carried out that led to the partial reconstruction of the minaret and the decoration of the internal and external facades through some frescoes.
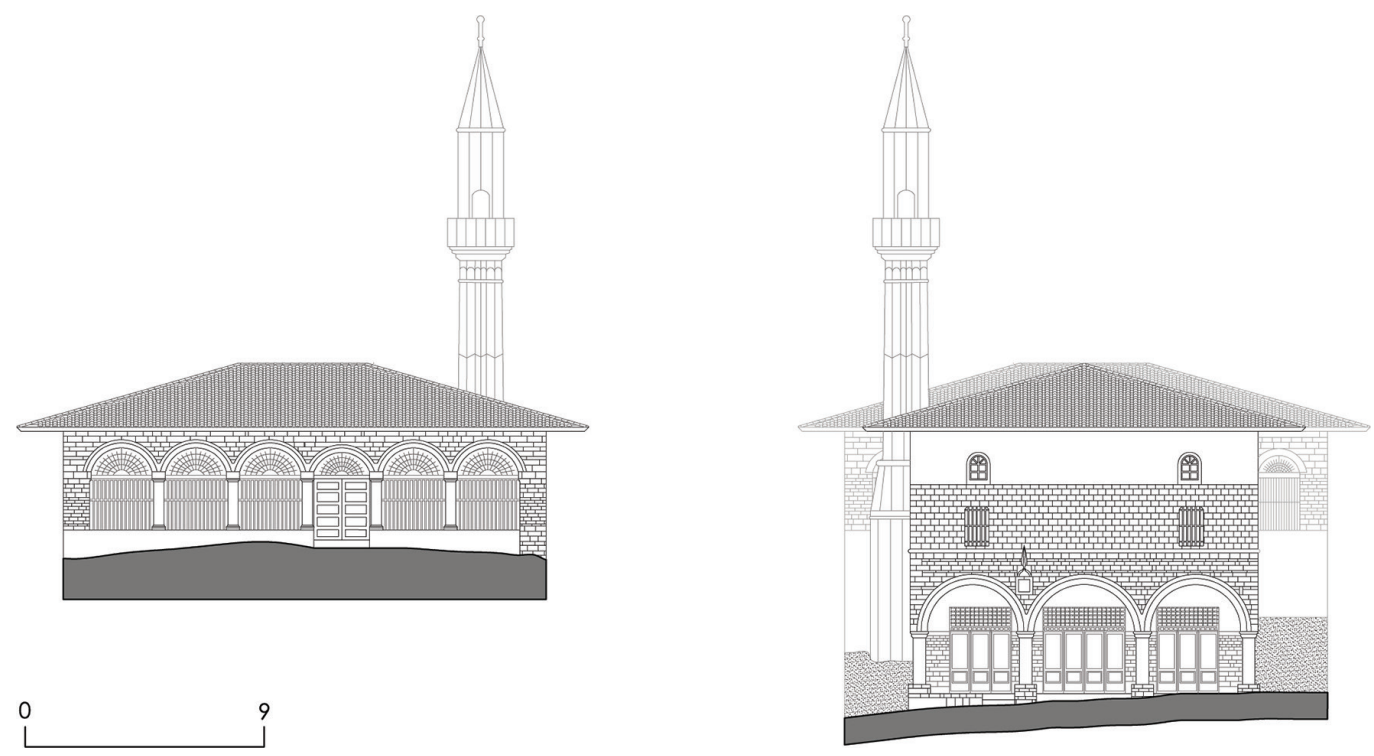

\section{Conclusions}

The survey conducted is a possible methodological example of reading the religious architectures of the city of Berat aimed at the elaboration of a digital archive containing a series of information acquired through the survey, from material to constructive and from dimensional to formal, of the religious architectures studied. The main objective was to elaborate a model ready to be used as a material for future architectural projects aimed at the conservation and enhancement of the architectural artefacts analysed. In this regard, the construction of digital information models for the restitution of complex organisms and digital photogrammetry techniques capable of reconstructing the external appearance of the architectures analyzed have favored the realization of this research. The contemporary software applications, in fact, have made it possible to directly control the data acquired through the survey and to process real digital archives that can remain open for continuous updates, monitoring and verification, and can be implemented with any additional data from archaeological, historical and documentary sources that may change over time. Through the proposed studies we intend to offer interpretative and operational tools capable of preventing and contrasting the problems arising from the enhancement and conservation with the aim of enhancing the collective knowledge of the cultural heritage of the Albanian territory, in most cases forgotten and not valorized [4]. 


\section{Notes}

[I]Treccani Dictionary, ad vocem.

[2] Treccani Dictionary, ad vocem.

[3] The city of Berat has been declared by UNESCO as "a rare example of a well-preserved Ottoman city and a shining model of peaceful coexistence of different religions in past centuries".

[4] This contribution has been made thanks to financing "Valere 2019" of the University of Campania "Luigi Vanvitelli".

\section{References}

AA.W. (1917). Itinerari Albanesi ( 892-1902), con uno sguardo generale all'Albania e alle sue comunicazioni stradali. Roma: Reale Società Geografica italiana.

Benedettini Benedetto, Gaiani Marco, Remondino Fabio (20 I0). Modelli digitali 3d in archeologia: il caso di Pompei. Pisa: Edizioni della Normale.

Bertocci Stefano, Bini Marco (2004). Castelli di pietre. Aspetti formali e materiali dei castelli crociati nell'area di Petra in Tansgiordania. Firenze: Edizioni Polistampa.

Bertocci Stefano, Parrinello Sandro (20 I5). Digital Survey and Documentation of the Archeological and Architectural sites. Firenze: Edifir Edizioni.

Corniello Luigi, Maliqari Andrea (2016). The Unesco site of Berat in Albania: the protection and the enhancement of the heritage. In Gambardella Carmine (a cura di). World Heritage and degradation, XIV Forum Internazionale di Studi Le vie dei Mercanti. Capri 16-18 giugno 2016. Napoli: La scuola di Pitagora editrice, pp. 1708-1717.

Corniello Luigi, Maiolino Francesco (20 I 4). Il rilievo come strumento di conoscenza. L'architettura sacra di Berat. In Giandebiaggi Paolo, Vernizzi Chiara (a cura di). Italian survey \& International experience. Atti del $36^{\circ}$ Convegno dei Docenti delle discipline della Rappresentazione. Parma 18-20 settembre 20|4. Roma: Gangemi Editore.

Docci Mario, Gaiani Marco, Maestri Diego (20l I). Scienza del Disegno. Novara: Città Studi Edizioni.

Fatta Francesca (20 I 6). La rappresentazione del patrimonio culturale tra finalità e innovazione. In Cicalò Enrico, Solci Margherita (a cura di). Modelli matematici e grafici per una ridefinizione delle prospettive/Mathematical and graphical models for a redefinition of perspectives. Roma: Gangemi Editore.

Gaiani Marco, Alessandri Claudio (1999). The Atrium of St. Mary Abbey in Pomposa: a hypermedial 3D network database. In AA.W. Eurographics '99- short papers and demo proceedings. Roma: Gangemi Editore, pp. 96-99

Galanti Arturo (I90 I). L'Albania: notizie geografiche, etnografiche e storiche. Roma: Società Ed. Dante Alighieri

Giordano Paolo (20 I4). Ridisegno, rilievo e riconfigurazione dell'Albergo dei Poveri di Napoli. Roma: Gangemi Editore.

Parrinello Sandro (20 I I). L'esperienza di rilievo e documentazione dell'Abbazia di Vallombrosa. In Bertocci Stefano, Parrinello Sandro ( acura di). Architettura Eremitica. Sistemi progettuali e Paesaggi culturali. Firenze: Edifir Edizioni, pp. I7-31.

Author

Adriana Trematerra, Università degli Studi della Campania “Luigi Vanvitelli”, adriana.trematerra@unicampania.it

To cite this chapter.Trematerra Adriana (2020). Reti e nodi nella città di Berat in Albania/Networks and connections in the city of Berat in Albania. In Arena A., Arena M., Brandolino R.G., Colistra D., Ginex G., Mediati D., Nucifora S., Raffa P. (a cura di). Connettere. Un disegno per annodare e tessere. Atti del $42^{\circ}$ Convegno Internazionale dei Docenti delle Discipline della Rappresentazione/Connecting. Drawing for weaving relationships. Proceedings of the 42 th International Conference of Representation Disciplines Teachers. Milano: FrancoAngeli, pp. 2787-2802. 